\title{
BICUSPID PULMONARY VALVE IN ASSOCIATION WITH CALCIFIC AORTIC STENOSIS
}

\author{
BY \\ J. B. ENTICKNAP \\ From the Department of Pathology, Guy's Hospital
}

The ætiology of aortic stenosis in the presence of a normal mitral valve is obscure, the major possibilities being old rheumatic infection and calcification of a congenitally abnormal valve. The present report describing a healthy pulmonary valve with only two cusps occurring in association with a typical extreme calcific aortic stenosis, therefore, throws some light on this subject.

Case Report. A married woman of 56 had a history of 5 years of increasing breathlessness. Eighteen months before she died she had a pain in the calf and chest, and a year later swelling of the ankles first appeared. She next developed pains in the abdomen and in the chest and then had transient congestive cardiac failure. Two weeks before death there was more chest pain and retention of urine; this contained protein and urobilinogen. The blood urea rose to $153 \mathrm{mg}$. per $100 \mathrm{ml}$. while the serum sodium and chloride fell to $290 \mathrm{mg}$. and $455 \mathrm{mg}$. respectively. Her E.S.R. was $21 \mathrm{~mm}$. in the first hour (Wintrobe). She died in uræmic coma.

Necropsy. There was slight icterus and some dependent œdema. The heart weighed $575 \mathrm{~g}$. and was covered with a fibrinous exudate from a small effusion. This cardiomegaly was due to hypertrophy of the left ventricle (average thickness $28 \mathrm{~mm}$.) and some dilatation of the right ventricle $(5 \mathrm{~mm}$.) and atrium. The tricuspid and mitral valves were somewhat opaque; the chordæ of the former were normal while those of the latter showed some thickening and shortening but no matting or grouping to suggest rheumatism. Both orifices were normal. The most significant abnormality was that the pulmonary valve had only two cusps, the posterior one being slightly larger and bearing at its mid point a transverse ridge-like elevation. They were quite transparent and there was no fibrosis. The circumference was $75 \mathrm{~mm}$. at the level of the commissures. The aortic valve was grossly diseased being irregularly calcified and ulcerated so that it formed a dome-shaped protrusion into the aorta. Its slit-like orifice was nearly antero-posterior and measured $19 \times 7 \mathrm{~mm}$; the front end abutted the nodule on the posterior pulmonary cusp. It seemed originally to have been bicuspid, too, its right-hand cusp bearing a nodule similar to that on the pulmonary valve. The right coronary artery arose from two orifices $2 \mathrm{~mm}$. apart in the anterior part of the right sinus in front of the nodule. There was a small mural thrombus in the right atrium.

There were multiple organizing pulmonary infarcts with effusions and evidence of chronic passive congestion in the other organs. Organizing thrombi of considerable age were present in the odematous calf of the right leg. There were no histological abnormalities in the myocardium, nor, apart from congestion and infarction, in the lungs. No organic cause for the uræmia was found.

\section{Discussion}

Aortic valves apparently composed of only two cusps are relatively common and though they are generally found to be stenosed there is little direct evidence of the cause of this distortion. Neither rheumatic infiltrations diagnosed histologically (Karsner and Koletsky, 1947) nor a clinical history reaching back into childhood (Campbell and Kauntze, 1953) are more than suggestive. Bicuspid malformation of the pulmonary valve, on the other hand, is extremely uncommon and a healthy bicuspid valve in a heart that does not have some fairly gross abnormality of septa or origin of great vessels may well be unique. Most examples occur in some form of the tetralogy of Fallot, 7 of the first 18 cases in the Guy's Hospital series of necropsies showing this abnormality: one of these had also aortic stenosis (Campbell and Brinton, 1953). In isolated pulmonary valvular stenosis apparent bicuspid malformation of the contracted pulmonary valve is much less common, none of 14 consecutive cases showing it, but one of these had a bicuspid aortic valve (Campbell, 1954).

Since a bicuspid pulmonary valve is usually associated with some other error of cardiac 20 


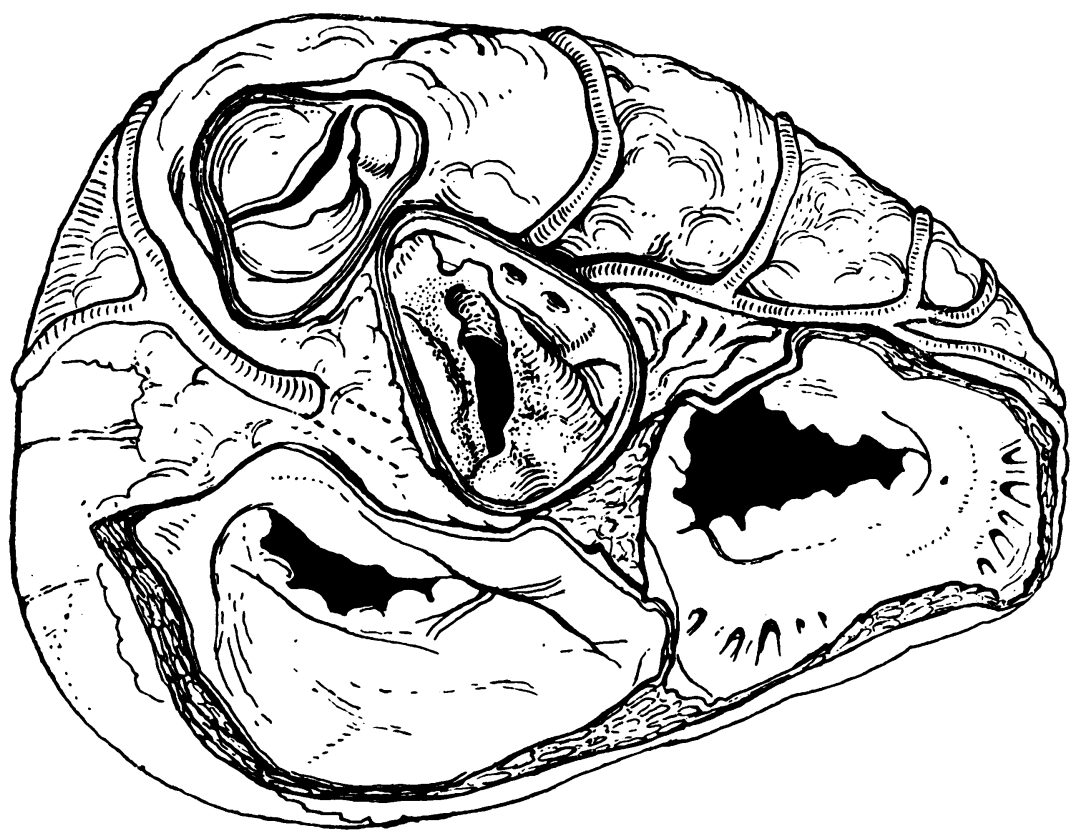

FIG. 1.-View of the base of the heart after dissection of coronary arteries and removal of atria and supravalvular parts of aorta and pulmonary artery. The pulmonary valve was normal except for the fact that it was composed of two cusps. The aortic valve was grossly distorted and calcified and seemed originally to have been bicuspid also.

development the associated abnormality in this heart was probably congenital in origin. This was, however, typical of the sort of aortic malformation that would, if present alone, commonly be considered to have developed after birth. This heart is described as a piece of evidence supporting the suggestion that many of these lesions, although first responsible for symptoms late in life, are in fact congenital in origin.

\section{Summary}

A case of congenital biscuspid malformation of a normal pulmonary valve in the absence of any other abnormality of the septa or orientation of the great vessels but associated with gross calcific aortic stenosis is described. The aortic malformation is apparently superimposed on a bicuspid form of that valve and it is suggested that the present case is evidence that some of these distorted aortic valves are congenital in origin rather than acquired.

I wish to thank Dr. Hampson, Physician to Guy's Hospital, under whom this patient was admitted, for permission to publish this report.

Campbell, M. (1954). Brit. Heart J., 16, 273.

\section{References}

C, and Brinton, W. D. (1953). Brit. Heart J., 15, 335.

-, and Kauntze, R. (1953). Brit. Heart J., 15, 179.

Karsner, H. T., and Koletsky, S. (1947). Calcific Disease of the Aortic Valve. Philadelphia. 